\title{
The hidden potential of pre-theoretical transversal events or advents of a Rainbow Nation
}

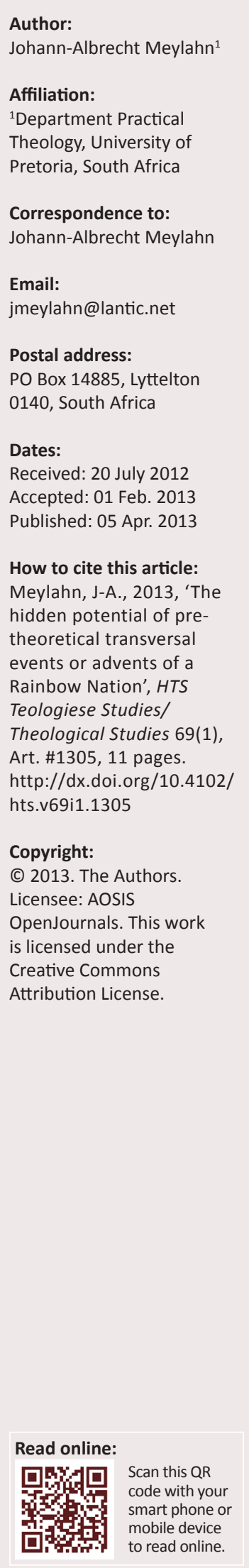

This article proposes that South Africa, as multi-lingual country, has unique potential and that this potential is not to be found in some or other essence of what it means to be African, but in the daily struggles, frustrations and possibilities of life in a fragmented and divided multilingual society. In this fragmented and 'impossible' society there are moments (maybe rare moments) of true understanding, communication, reconciliation and forgiveness and these moments I call 'Advents of a Rainbow Nation'. Although these Advents can be understood (made reasonable) via the transversal reasoning of Welsch and Schrag, this article would like to propose an alternative: to wonder-off in a different non-direction namely into the u-topic and u-chronic clearing of non-philosophy. Reason cannot receive the Advent as gift (given without givenness) and thus transforms the Advent into a philosophical event of thought. In the process of seeking to understand these Advents as events, the Advents are transformed by a Decision or cut of transversal reasoning, and so the Advents themselves are lost. Therefore, what is sought in this article is not an understanding (reason) of this Advent, but rather a wandering in and a wondering at the grace and faith of this Advent. This grace and faith is the greatest epistemological asset South Africa, as multi-lingual country, can offer a plural global world as it opens a space for non-philosophical thinking: thus thinking science, religion, art, literature together in a vision-in-One with theology safe-guarding this vision-in-One unifacially facing the future. The question is, can South Africans embrace the multiplicity of the Advent of the Rainbow Nation? Can the Church with her Christ narrative sojourn with South Africa towards a rainbow nation and thereby facilitate a noological space for multiple connective intellection, or is she an obstacle towards developing this potential?

This article proposes that South Africa, as a multi-lingual society and therefore a micro-cosmos of the global world, has a unique potential and that this potential is not to be found in some or other essence of what it means to be South African, but rather in the daily struggles, frustrations and more specifically in the survival of these struggles and frustrations in living in a fragmented and divided multi-lingual society.

In this fragmented and 'impossible' society there are moments (maybe rare moments) of understanding, communication, reconciliation and forgiveness and these moments I call Advents ${ }^{1}$ of the Rainbow Nation and as such they are moments of grace as they are gifts: a given without givenness (see Laruelle 1999, 2000). These Advents are gifts prior to a cut or a decision via some or other rationalisation or theoretical explanations. However, there is the innate human desire to understand and to make reasonable such Advents with the noble purpose of maybe multiplying such Advents, but by doing so, these gifts (Advents) are transformed from Advents (gifts: given without givenness) into rational and/or theoretical and/or reasonable events via a philosophical decision in order to develop systems or codes that can be repeated and exported. Inevitably, in the process of rationalisation the Advents are not repeated, but destroyed.

Postmodern theories in their various forms seek to come to terms with plurality and/or heterogeneity or multiplicity and have sought various creative ways of understanding this multiplicity, or stated differently, developed conversations within a context of plurality. Two of the most prominent and most effective rationalisations of plurality beyond both the foundationalism of modernity and the non-foundationalism of certain interpretations of postmodernity are found in the thoughts of Wolfgang Welsch and Calvin Schrag. The article will focus on Welsch, as the father of transversal reasoning, and unpack how Advents are transformed into reasonable systems or codes via philosophical decision. I believe that such a system or code can best be described with Lacan's discourses of the master and/or discourse of the university (see Lacan 1991). It will be argued that any such rationalisation into a system or code destroys 
the Advent. An alternative will be proposed: to wonderoff $^{2}$ in a different non-direction namely into the u-topic and $\mathrm{u}$-chronic ${ }^{3}$ clearing of the non-philosophy of François Laruelle (2010) and thus be in a state of wonder by becoming a stranger in the world. ${ }^{4}$

Both Welsch (2008b) and Schrag (1992) argue that their respective forms of transversal reasoning are grounded in either everydayness (Welsch 2008b) or in pre-theoretical everyday communicative practices (Schrag). These practical everyday Advents inspired the development of their reasoning system that enabled them to make sense of these everyday Advents and develop a transcendental theory to explain these Advents. If one takes the South African situation into consideration there are moments where intercultural or multi-cultural communication is 'successful': Advents of a Rainbow Nation. The question that is immediately asked is: Why are there such Advents? How is this possible? Once these Advents are made reasonable via sufficient philosophy the theory can be exported beyond the everydayness into various levels of abstraction. The Advent of multi-lingual understanding, communication and reconciliation can indeed be understood via various theories based on transversal reasoning and these theories can then be taken to the next level of developing a universal theory of trans-disciplinary reasoning as a kind of post-foundational epistemology (see Van Huyssteen 1997). However, in the process of seeking to understand (make reasonable) these Advents, the Advents are lost and they are transformed into some or other master or university discourse (see Lacan 1991). The moment the Advents are transformed into events of transversal reasoning these events are open to the misuse of power and thus can easily be transformed into an ideology. Therefore, what is sought here is not an understanding (reason) of these Advents, but rather a wandering into these Advents and a wondering at these Advents, thereby becoming a 'stranger' subject ${ }^{5}$, and at the possibilities this opens to view the world anew: vision-in-One as a world unifacially turned towards the future. This givenness (grace) and unifacial turning is the greatest asset South Africa as multi-lingual country can offer the global world as it offers faith alone (sola fide) - not in theory and most certainly not in ideology, but faith in the Advent itself as gift (sola gratia) that is received in faith.

This article will describe this wandering - wandering in its homophonic meaning as both a wandering and wondering.

2.Wonder-off specifically spelt as wonder rather than wander, because this wandering is more of wonderment than a wandering with a specifically planned destination.

3.See Laruelle's (2003:181) discussion on non-philosophy's orientation towards the future and the utopia of the real.

4.'This arrival is an "advent" that comes from nowhere, that presents again what was already present, but now turned towards and into the invisible face of the Strangersubject. In this turning the given is itself estranged, for it is identified with the unseen face - the solitary and unilateral face of the future, or of the present as it faces the future for the first time' (Alkon \& Bunjevic 2011:219-220).

5.See Laruelle (1999:146): 'The non-philosophical subject distinguishes itself form the subject which is philosophical in type. It is a purely transcendental subject, distinct from the real Ego, turned toward the World to which it is a stranger and towards which it turns itself as stranger.'
A Nietzschian wandering 6 , but together with a wondering as both puzzlement and amazement, which means to be in a state of wonderment as only a 'stranger' subject can be; the wonderment that in a multi-lingual context, communication is sometimes 'successful' and this successful communication are moments of forgiveness, reconciliation and thus rare gifts of a Rainbow Nation. Why do I say that?

Jacques Lacan argues in his discourse theory that communication is always a failure (Verhaeghe 1995). He argues that communication is necessarily a failure because of certain structural linguistic constraints or as Michel Serres would argue because of various levels of noise (Serres 1982:125-126). For Lacan the basic structure of communication is made up of four positions that can be arranged as in an algebraic formula. There is an agent (subject) who seeks to communicate something, a truth, to somebody other and finally the product of this communication which is the message that the other receives (see Meylahn 2010:1 of 9). Yet the product of communication (message received) is never equal to the truth that the subject intended to communicate. Between message received and truth desired to be communicated there is always a gap. One can understand this gap by introducing Jacques Derrida's idea of différance as both difference and deferment (Derrida $1982: 7$, n. 7). The truth one wants to communicate might be something present (that is to say, something present that I see): the referent. To be able to communicate this truth to somebody else something needs to be added to this referent (presence). I see for example a beautiful dog (German pointer) and I wish to tell my wife about this beautiful dog that I am seeing. I need to add something to the presence 'out there' so as to communicate concerning its presence to my wife. The presence itself needs to be supplemented so that it becomes communicable. The dog 'out there' needs to be supplemented with the word 'dog' (German pointer) for me to be able to send my wife a message concerning this 'dogout-there'.

The referent and/or presence needs to be supplemented with something that is other to it so as to communicate it to somebody else (see Derrida 1997:141-164). This supplement is always an in place of and thus also the absence of the referent (truth). Thus the supplement (sign) is like a pharmakon (see Derrida 1981:99f.); it is intended to be a remedy to help me communicate the beautiful presence of this German pointer to my wife, but in being a remedy it is also a poison. It is intended as a remedy to keep whatever is present, present over time and space, but in the attempt of keeping the fleeting presence present it destroys the presence as that which was present is absent in the supplement. Thus this supplement intended as a pharmakon is always both remedy and poison. The signifiers that one uses to communicate something to

6.From The Wanderer: "He who has attained the freedom of reason to any extent cannot, for a long time, regard himself otherwise than as a wanderer on the face of the earth - and not even as a traveller towards a final goal, for there is no such thing. But he certainly wants to observe and keep his eyes open to whatever actually But he certainly wants to observe and keep his eyes open to whatever actually happens in the world; therefore he cannot attach his heart too firmly to anything individual; he must have in himself something wandering that takes pleasure in
change and transitoriness' (Nietzsche 1964:405f.). 
another are always characterised by both difference and deferment (Derrida 1982:7). Thus the basic communication structure is characterised by the inability to completely and conclusively communicate a truth to another and this inability is based on a structural linguistic impossibility (Meylahn 2010:2 of 9). It is for this reason that the world continues to communicate. Serres uses the image of a square to reflect on communication and argues that there are four positions in this square. There is the position of the subject (who wishes to communicate something), the position of the other (who is the intended recipient of the communication) and the other two positions are noise (that which disturbs communication) and code (that which seeks to reduce the noise to a minimum) (Serres 1982:126). Noise can be reduced to a minimum but it can never be completely avoided as there is always a level of disturbance (the possibility for miscommunication) in any communication.

Therefore communication is plagued by this inability and impossibility. There will be many who would argue that this is not true as we communicate all the time and we do it successfully. We currently live in the communicationinformation age with continuous instant communication of terabytes of information. Thus there is successful communication where the message (letter) always arrives at its destination as Lacan (1972:72) argued in his Seminar on the Purloined Letter. However, Lacan is not arguing for the success of communication, as it was Lacan who argued that communication always fails. When he argues that the letter always arrives at its destination he is actually arguing not for the success of communication, but the success and power of the structure of discourse. He is arguing for the power of theory and philosophical decision. In other words, this miscommunication (inability and impossibility of communication) is placed in a particular discourse. For Lacan there were initially four possible discourses: master, university, hysteric and analyst (Lacan 1991) and later he also developed the discourse of the capitalist (see Meylahn 2010). Once placed in the particular discourse the letter is always found where it is meant to be (Lacan 1972:72) and thus one has the illusion of successful communication and the illusion that one has a grip on reality. Serres's code can be compared to Lacan's various discourses that cut into the noise seeking to minimalise it. The code is knowledge or theory or reasoning or discourse and is always combined with power so much so that one can argue: 'It is always a wolf, and not a lamb, who quenches his thirst upstream in the transparent stream of pure reason' (Serres 1982:18).

Derrida, in his response to Lacan's Seminar on the Purloined Letter (Derrida 1975:107), argues that the letter perhaps arrives or perhaps does not arrive at its destination. There are these Advents where the letter arrives un-expectantly. It arrives and it is always still to arrive un-expectantly, unplanned, unreasoned, beyond discourse or code, by grace and faith alone. This is indeed the experience of Advents of the Rainbow Nation in South Africa where one is surprised by joy as there is communication, reconciliation and thus forgiveness, but these are Advents of grace as they are unexpected (unconditioned) gifts: given without givenness.
The experiences of these Advents, of the un-expectant arrival of the letter, invite one to seek to understand this grace, but in the process of seeking a reasonable account (calculability) of this arrival, the incalculability of the Advent is destroyed and instead of the Advent one has two possibilities: either the letter never arrives at its destination (various forms of nihilism) or it always arrives at its destination (various forms of positivism).

Schrag and Welsch, in their attempts to find sufficient reason (sufficient philosophy) for this given, specifically the given of the multiple in plural contexts, tried to navigate a path between these two extreme possibilities (see Welsch 2008a:1 of 9). Schrag appeals to the resources of rationality, a transversal logos or rationality that is neither in the classicalAristotelian tradition of Logos nor the anti-logos tradition (see Schrag 1992:166).

Both authors seek to find reasonableness in the postmodern condition of plurality or multiplicity. In mono-linguistic societies there is a lot of harmony because the code is powerful and can reduce the noise to a minimum, and likewise in mono-disciplinary discussions, yet the problem is highlighted in multi-linguistic or multi-disciplinary conversations as in such conversations the noise is heightened because of the problem of translatability. In such multilingual or interdisciplinary conversations the noise needs to be overcome by the development of a new code and this new code inevitably will become a master, hysteric or university discourse. A new, more comprehensive or holistic code of reason needs to be developed that has the ability to integrate the various rationalities into a new comprehensive whole or totality so that the letter arrives at its destination.

This postmodern condition of plurality is the everyday experience of life on the South African streets as a microcosmos of the global world where one is confronted with the other with her different reasoning strategies and resources. The experience of the other was also the starting point for Welsch (2008b) as he tried to find out what rational capacity there is that makes such an experience with the other possible and successful. He begins by taking a closer look at reason in practice. ${ }^{7} \mathrm{He}$ does this by taking an everyday situation into account and in this article an everyday situation in the lifeworld of South Africa is taken into account. This everyday communicative situation is thought as a philosophical event and it becomes an event of thought. Later I will return to Laruelle who argues that the Advent is the Advent of thought [la pensée], that is to say the force (of) thought (Laruelle 2000:187), but before I return to Laruelle, Welsch will be followed in the transformation of the Advent into an event of thought via a philosophical decision. As mentioned above the situation of being confronted by an other, particularly an other of a different cultural-linguistic and even racial background, will be taken into account. In this encounter one 7.Welsch wanted to 'analyse the extent to which our mental procedures imply practices of reason and to consider what reason's constitution must be like in order to allow such practice' (Welsch 2008b:4). 
is convinced, for whatever reason ${ }^{8}$, that the other has a point against one's own position on a specific topic. For Welsch the reason why the other point is taken seriously is purely philosophical as the other might have a point and thus it is worth my while to at least take her point temporarily seriously. For whatever reasons one takes the other's point seriously, it is taken seriously on the presumption that the other has reasons for believing or having this position, and therefore there is potential validity in that point of view and this validity is worthy of investigation.

This investigation follows the path of the reconstruction of the opponent's objections to one's own point of view (Welsch $2008 \mathrm{~b}: 5$ of 16). This means that there is a step back from one's own framework so as to enter the framework (rationality) of the other's thinking in which her objection makes sense and possibly good sense. Welsch argues that this reconstruction work is a 'precondition for any counter-arguments being reasonable, instead of just strategic' (Welsch 2008b:5 of 16). The next step is to consider the validity of the objection with respect to one's own position. Different results are conceivable:

- The objection does not apply to one's own position at all because of a conceptual misunderstanding.

- The objection is valid, but only within the framework of the other's thinking and thus it challenges one's own framework.

- You need to investigate further as one is uncertain as to the extent of the applicability of the other's position with regards to your own (Welsch 2008b:5 of 16).

Whatever the outcome of this encounter, what has happened in this encounter is that one's own position has been opened up to the possibility of other positions. One finds oneself in a position of vulnerability as one's framework (rationality) has been questioned by the other. The way to move beyond this vulnerability is via a philosophical (framework) decision. To place Welsch's arguments into the context of Lacan and Serres, the way to move beyond the vulnerability is to decide on a code (see Serres 1982:125f.) within which to reduce the noise (vulnerability) or to decide on a discourse (Lacan 1991) with which to master the situation of vulnerability.

For Welsch it was important to move beyond the vulnerability caused by these opposing frameworks, and deciding which of these frameworks or positions are right or wrong, is for him not the solution, because whatever argument is put forward in defence of a particular framework is dependent on that specific framework for it being right or wrong (Welsch 2008b:6 of 16). The question therefore is how to get beyond positional frameworks? Welsch does not opt for the idea of seeking common ground because common ground would just be another framework. In an attempt to understand the human capacity for the above described encounter, Welsch takes a step back rather than focussing

8.1 say for whatever reasons as there might be different reasons why one comes to the conclusion that the other has a valid point to make. It could be insight or it could be motivated by a force of circumstance the other might be your boss and thus you have to take that point into consideration or it might be motivated by political you have to take that point into consideration or it might be motivated by political
correctness. Thus there are various reasons why the other position is taken into consideration. on the frameworks and entering into the war of frameworks (see Welsch 2008b:7 of 16).

This capacity cannot be represented by any one of the positions (frameworks) involved in the play and yet there seems to be nothing other at play than these various positions. Welsch was in search of some other capacity, namely a capacity that is not 'restricted to one of the single positions and is nonetheless permanently involved in considering their interplay' (Welsch 2008b:7 of 16).

It is the search for capacity ${ }^{9}$ that recognises the limits of positional thinking and constitutes the relentless power of reflection on these matters. For Welsch this capacity is reason as it is the relentless reflection and self-reflection which is constitutive for reason and constitutive for philosophy as a self-reflection. Welsch differentiates between reason and rationality..$^{10}$ Rationality can be compared to the various reasoning frameworks, that is, a particular rationality of a particular discipline, whilst reason is the ability to rationalise without any specific content. Thus reason and rationality cannot be separated because rationality is dependent on reason (Welsch 2008b:2 of 16) as reason is the limit and possibility of the various rationalities. Welsch argues that this reason is as pure as it is free of content and devoid of any possessions. ${ }^{11}$ Reason that is pure, as it does not have any content as it has no knowledge, brings it very close to Lacan's discourse of the analyst who also does not have any knowledge (no specific content); the only knowledge the analyst has is the knowledge of pure différance (Meylahn 2010:6 of 9). Yet as a capacity of reflection and of unlimited reflection it must be in the possession of a few properties, but the properties are pure logical properties alone. This reason is the holder of logic operators. ${ }^{12}$ Reason must employ these and thus reason is essentially a logical capacity. It is because of these logical and formal categories devoid of content that reason can be interpreted as pure.

Welsch's ideas are perfect for understanding (discovering a reasonable reason for) South Africa as a multi-lingual context, yet this reasonable reason (or pure reason) relies on what he calls logic (difference-identity, cause-effect). He has attempted to develop a pure code without any content - in a sense a pure mathematical (logical) code that can be

9.'This capacity is involved from the start, and from the start exhibits the most amazing characteristics, It is not bound to a specific position (otherwise it could not develop every position's alternative interpretation of another position's topics); develop every position's alternative interpretation of another position's topics); it is extremely flexible (otherwise it would not be able to establish the whole range of alternative interpretations); it is able to adjust perfectly on the spot (otherwise it could not develop these interpretations in a manner truly faithful to the single positions' stances); and it is neutral (otherwise it could not provide a fair comparison of different reciprocal interpretations - through to stating their equal validity and ultimate undecidability)' (Welsch 2008b:7 of 16).

10.'It seems appropriate to distinguish self-directed reflection from object-directed reflection and to parallel this with the distinction between reason and rationality - or, in older terminology, between reason and understanding. Rational reflection (or first order reflection) refers to objects; reason's reflection, however, is a second order reflection which refers either to the procedures or rationality or to the procedures proper to reason' (Welsch 2008b:2 of 16).

11.'Reason is free of such presuppositions and prejudices. In other words: reason is pure reason - else it could not be reason at al' (Welsch 2008b:8 of 16).

12.Logic operators 'such as the principle of contradiction, elementary categories like identity and difference, singularity, multiplicity and totality, constancy and change, cause and effect, ground and consequence, conformity and contradiction, potentiality and necessity, unity, particularity, coherence and so on' (Welsch 2008b:8 of 16) 
used to make sense (reasonable) of the interaction between various loaded codes or loaded frameworks. In a sense, Welsch has developed a philosophy of philosophy as he has sought not a specific rationality (framework), but the reasons or reasonableness of rationalities. He has sought to discover what makes rationalities reasonable and thereby he has exposed both the possibility and limitation of the various rationalities as reflected from an over-view position of a meta-philosophy.

Yet even if one does not choose a specific rationality or seek to remain within pure logic, that does not prevent transversal reasoning developing into a university discourse or even master discourse, although Welsch argues that transversal reasoning is no meta-language or meta-philosophy and is inconclusive (Welsch 2008b:9 of 16). It strives for totality (Welsch 2008b:11 of 16) or holism in Schrag's terminology. The underlying power is this striving towards totality or holism as unity in diversity and this desire of unity in diversity drives the discourse, drives the communicative practice, and in a very real sense predetermines it. Thus one can argue that the letter always arrives at its destination as there will be unity, there will be a totality, but it will always be the totality of the powerful: the powerful majority or the economically powerful or the power of political correctness or the power of whiteness or the power of blackness, it depends on the discourse. Serres helps us to understand that Lacan's letter is always arriving at its destination with his interpretation of the wolf always drinking upstream from the lamb, as the reason of the stronger is always the best, even in the pure waters of pure logic (Serres 1982:15). It is in this sense that transversal reasoning and communicative practice with its drive for totality becomes an ideology both in the classical Marxist sense ${ }^{13}$, but also as Laruelle (2003) argues:

In philosophy, the combinatory structure or system continues to predominate so that philosophy can only posit the One-Other as a term in the guise of something that remains an 'ideological' artefact: an effect or result that has been abstracted from the process through which it was produced. (p. 176)

This pure logic is never pure as it is impossible and thus the belief in its purity opens it to become an instrument of the dominant powers.

Laruelle (2010) in his book Philosophies of Difference describes Nietzsche, Heidegger, Deleuze and Derrida as philosophers of difference who all tried to understand the philosophy of philosophy or rather the philosophy of metaphysics. These various thinkers all in their particular ways tried to understand the limitations and possibility of metaphysics and thus they can be grouped as the post-metaphysical thinkers, but according to Laruelle they remained philosophers of decision (Laruelle 2010). The structure of philosophical decision is a fractional structure comprising

13.Ideology taken to mean how it is understood in the classical Marxist definition, "ideologies are discourses that promote false ideas (or "false consciousness") in subjects about the political regimes they live in. Nevertheless, because these ideas are believed by the subjects to be true, they assist in the reproduction of the existing status quo, in an exact instance of what Umberto Eco dubs "the force of the fake". To critique ideology, according to this position, it is sufficient to unearth the truth(s) the ideologies conceal from the subject's knowledge' (Sharpe 2005).
$2 / 3$ or $3 / 2$ terms. ${ }^{14}$ For Derrida, différance is both difference and deferment, but this difference and deferment is intratextual and not a description of a relation to exteriority. Différance is not an attempt to describe reality or to constitute reality. So the 3 is indeed a supplement of identity, but not added on to ' $x$ ' as all there is, is supplement or all there is, is text (see Derrida 1997:158). Thus the supplement is divided in itself as both presence and absence or as both remedy and poison. It is divided in itself as difference between what a sign is and what it is not. It is not the difference between the sign and its Other or referent. It is not only difference, but also deferment as the absence of presence over time (Derrida 1982:7). There is a non-relation to the Other or an arbitrary relation to the Other, but this arbitrary relation is not capricious because of an instituted trace (Derrida 1997:46). Thus the 2 is not subtracted from the identity in order to constitute it, because what différance constitutes is not the Other, but it constitutes itself as writing: a necessary and unavoidable supplement, not of reality, but of a supplement: an infinite chain of supplements never reaching beyond supplementarity. Différance, language, writing is all there is (see Derrida 1997:158). This can be translated into constituting 'what is'. What is, is writing according to writing (différance): all there is, is writing, yet with that Derrida does not deny reality or the Other, but all he denies is that one can have access to the Other without language (see Derrida's response in an interview in Kearney 1984:123-124). Thus language constitutes itself as différance as opposed to presence. Laruelle describes decisional-philosophy or philosophy of difference as a relation between ' $x$ ' (relation) and ' $y$ ' (non-relation) (Brassier 2003a:27). This, Laruelle challenges with his nonphilosophy and its relation with decisional philosophy in terms of a non-relation of relation (' $x$ ') and non-relation ('y') (Brassier 2003a:27). Even Derrida's relation and nonrelation is still thought, the Other is absolutely Other and as such thought as absolutely Other and therefore it is still thought as a relation with a non-relation. ${ }^{15}$ Derrida's idea of différance remains a kind of overview or a meta-philosophy of the relationship between writing and its other even if that relationship is a non-relationship and in that sense it remains a form of idealism.

Derrida, with his idea of différance, argues that writing encloses itself (autonomous), yet there remains an opening toward the Other, a haunting of writing by the Other via the trace. Laruelle is not arguing that this philosophy fails, because it fails to the same degree that it succeeds, or as Serres argues that systems work because they do not work. Non-functioning is essential for functioning (Serres 2007:79). It fails or succeeds because the letter always arrives at its destination:

14.The $2 / 3$ fraction Laruelle identifies with Nietzsche and Deleuze the 2 qua difference between $\mathrm{x}$ and $\mathrm{y}$ is divided by the 3 as identity of that difference, but an identity that has to be added on to it as its necessary supplement in order to constitute it (Brassier 2003b:170). The other possibility which Laruelle ascribes to Heidegger and Derrida is the ' 3 qua supplement of identity added on to $x$ and $y$ is divided by the 2 as their difference which has to be subtracted from their identity in order to constitute it' (Brassier 2003b:170).

15.The attempt at understanding the end of philosophy is still an attempt at understanding the essence of philosophy as an 'auto-positional essence indefinitely closing on itself, whilst missing or exceeding itself by a difference intrinsic to that closing on itself, whilst missing or exceeding itself by a difference intrinsic to that
identity, so that it never fully achieves either a perfect closure or a perfect opening' (Laruelle 2003:173).
(Latity, so that it never 
because the structure - specular in nature - is divided by a difference or alterity that remains subordinated to its identity, the whole forming a dyadic/triadic structure that is equally and simultaneously open and closed. (Laruelle 2003:173)

The focus is always either on identity or difference or alterity and this focus defines philosophy as theoreticist idealism or idealist theoreticism (Laruelle 2003:173). For Laruelle every philosophy is bound to a specularity that it mistakes for the real. ${ }^{16}$ This has certainly characterised philosophy from the Greeks to Hegel. With the rise in various forms of deconstructionist philosophies (Nietzsche, Heidegger and Derrida) began the acknowledgement of philosophy's autoclosure, yet this auto-closure of philosophy is simultaneously enabled and hindered by an alterity that haunts it. This alterity is partially extra philosophical yet it ratifies philosophy's basic sufficiency (Laruelle 2003:174).

Laruelle argues that these various philosophies of difference are about a decision or cut, thereby placing over and against the One or Real a philosophical decision in the case of Nietzsche, Heidegger, Deleuze and Derrida various philosophies of difference with which they seek to understand not necessarily the One, but rather a self-reflection of philosophy itself. They seek to understand the limits and possibilities of philosophy or metaphysics itself. Heidegger's Überwindung der Metaphysik or Derrida's closure of metaphysics is an attempt not to destroy metaphysics or philosophy and even logocentrism, but to understand the possibility thereof and thereby expose the limits. Thus one can argue that they have truly come to the end of philosophy as they reflect on the limits and the very condition of philosophy itself. Yet they do not move beyond philosophy, as Derrida rightly responds to Levinas' attempt to move beyond philosophy by quoting a Greek who argued that not to philosophise is still to philosophise (Derrida 1978:152) and that any attempt to move beyond philosophy is still philosophy. Levinas responded to this critique by arguing that there is a way beyond philosophy for thinking (Levinas 1998:77).

Thus, to return to Welsch, although he shifts the decision from a decision between various philosophies to a decision of philosophy itself (reason or logic) it still remains a decision. Thus philosophy is a parasite - to borrow the idea of a 'parasite' from Michel Serres's book The Parasite (2007) - that takes without giving. A parasite cuts (bites) into the host body and takes from this host body without returning anything to it. Serres describes his idea of the parasite by reflecting on La Fontaine's fable of the town and the country rat (Serres 2007:3-15). Everything that occurs in the fable is interpreted as a kind of theft or interruption of the flow of things. This interruption can be interpreted as Laruelle's cut or decision and this cut or decision would then be the parasite. In the book The Parasite Serres develops three different kinds of meaning of the Parasite and these three meanings coincide to develop a new kind of logic, namely a parasitic logic. This logic is made up of: 'analyse (take but do not give), paralyse (interrupt the usual functioning), catalyse (force the host to 16.Philosophy is "bound to the primacy and priority of theory as reflection of the real - the two together constituting "speculation"' (Laruelle 2003:173). act differently)' (Brown 2002:16). If these three aspects of the parasitic logic are read together with Laruelle's (2010) non-philosophy one can argue that various philosophies (philosophies of difference) parasite on the One (host) by analysing what is, paralysing (interrupting) the One by the cut or decision and then catalysing by forcing the One to act differently, but in the process not discovering anything of the essence of the One and therefore not truly giving anything back to the Host or One (Laruelle 2010). He argues that these various philosophies of difference focus thus on their selfreflection and the impossible possibility of philosophy, that they ignore the One, they seek the essence of philosophy without seeking the essence of the One.

Philosophy (decision) takes the One - that which is given (the unconditioned Advent) and transformed into a system of reason (analyse) via a decision or cut (paralyse) - by placing it into an economy, thereby transforming the One (catalyse). The decision brings the Advent into circulation and thereby destroys it. To this decision (philosophy) Laruelle proposes a non-philosophy where something is given without givenness (Laruelle 2000:185) - the exact opposite of the parasite who takes without giving. For Laruelle, the One is a:

question of positing the non-thetic root of decision axiomatically, without presupposing it via decision. Or (which comes to the same thing) of presupposing it via an axiom rather than positing it via decision. (Brassier 2003a:28)

One can argue that that is what Welsch tried to do - he tried to understand the everyday experience of plurality that is given to thought, by seeking sufficient philosophy (reason) to understand this plurality and thereby transforming it into an event of thought. Yet, in trying to reason this plurality he brought in this duel between transversal reasoning and the event of plurality and he interpreted the plurality of experience in terms of transversal reasoning, which once again functions according to a parasitic logic. Laruelle opposes this duel with the dual understanding of decision and the One, seen not as opposing each other, but seen together as givenin-One. The relation between One and decision (philosophy) is not longer a duel, but an unilateral duality of the vision-inOne (Laruelle 1999:143). The One given without givenness and the various parasites (philosophies or frameworks or university discourses or even the discourse of the analyst) are various decisions and these decisions are occasions of thought and all this needs to be seen together as a vision-inOne; as an Advent of thought.

Laruelle's non-philosophy, or vision-in-One, is an attempt to move beyond the circularity of philosophical decision by exposing that inevitable circularity. How can this inevitable circularity be exposed as any attempt of moving beyond philosophy to inevitably remain philosophy, as Derrida argued?

Laruelle will separate or 'dualyse' the two moments of philosophical decision, namely presupposition and position, without these two entering into a duel. Thus, what Laruelle does with his non-philosophy is a non-Decisional cloning of Decision (Brassier 2001a:217). 
This non-Decisional immanence (non-philosophy) is first presupposed:

without being posited - in its radical autonomy as immanence, which is to say, as foreclosed to Decision, the better to be occasionally posited - without being presupposed - as a transcendentally foreclosed but nevertheless determining condition for philosophical Decision. (Brassier 2001b:69)

Thus one separates the gesture of presupposition from philosophical position and simultaneously separates immanence from its transcendental effectuation (Brassier 2001b:69).

In the first move of this dualysation immanence is presupposed without position in its foreclosure to decision. Immanence is presupposed as a minimal necessity for thought, but without thinking this presupposition from a particular philosophical or scientific position, but rather as foreclosed to such decision. That is to say, immanence is presupposed without thinking it from the view of either idealism or materialism or empiricism or language over against presence on the basis of différance or Unterschied or transversal reasoning. The immanence presupposed is utterly empty and transparent without any content of some or other philosophical position. This is the presupposed minimal precondition for thought. There must be something out there for thought to be possible. There must be an Other to writing, although that Other cannot be known and thus it is foreclosed to decision. It is the presupposed necessary condition of thought, but without it being conditioned. It is an empty or negative condition as it does not have any positive content and therefore it is not ontologically sufficient, although it is necessary for thought and thus it is a necessary, but insufficient condition for thought. ${ }^{17}$ It is presupposed as foreclosed to the advent of philosophical decision. This is no different to what Derrida argued, that the Other is foreclosed to thought, but it is the necessary condition of thought as it is presupposed, but Laruelle no longer thinks of this as the Other or the relationship or non-relationship with this Other, but as immanence presupposed without position. It is no longer a situation where you have the One (Same) and the Other related in some way directly (idealism or materialism) or indirectly as non-relation (différance) only thinkable on a meta-level, but a presupposition without a position defining the relation to it.

In this second moment is where Laruelle's radical or heretical stance $^{18}$ is revealed in the sense that he does not wish to revolutionise philosophy and provide the ultimate position, but he exposes the hallucinatory character of all philosophical

17 .'Since the One is nothing but the being-given-without-givenness (of) the One, it in no way produces philosophy or the World (procession, emanation, ontologicoekstatic manifestation, creation ex nihilo, onto-theo-logical perfection) - there is no real genesis of philosophy. This is the non-sufficiency of the One as necessary but non-sufficient condition. The Real is a "negative" condition or condition sine qua non for.... precisely because it is not itself nothingness or negation. A givenness of philosophy is thus additionally necessary if the vision-in-One is to give philosophy according to its own mode of being-given' (Laruelle 1999:142).

18.'Laruelle prefers heresy to revolution. Where philosophical revolution involves a reformation of philosophy for the ultimate benefit of philosophy itself - and a philosophical stake in what philosophy should be doing - heresy involves a use of philosophy in the absence of any philosophically vested interest in providing a normative definition of philosophy' (Brassier 2001b:25) positioning or Decision ${ }^{19}$ as being circular and self-sufficient. He argues that only by virtue of being presupposed as the necessary but non-sufficient condition, is immanence posited as given without givenness (without presupposition) 'on the occasional basis of philosophical Decision, as transcendentally necessary for Decision' (Brassier 2001b:69). Thus, non-philosophy posits immanence on the occasional (arbitrary) basis of some philosophical Decision as what is transcendentally necessary for that Decision..$^{20}$ 'Only on the occasional basis of philosophical Decision can immanence be posited as transcendental and thereby become positively effectuated as a necessary condition for Decisional thought' (Brassier 2001b:69), but without the One or the Real being affected by Decisional thought. ${ }^{21}$

What non-philosophy exposes is this circular character of philosophical decision and its hallucinatory self-sufficiency. To this circularity of philosophical Decision Laruelle proposes a heretical alternative vision-in-One. In this vision-in-One the relation-non-relation of philosophy and world is cloned as the relation world-thought (see Alkon \&Gunjevic 2011:219) as a vision-in-One: the Real or One. In other words the world is only as it is thought. There is no world beyond thought. This can be interpreted as a radicalisation of Derrida's, there is no outside text, all there is, is text or writing (Derrida 1997:158). All there is, is the Text or Context, but without the absolute abyss of the Other, because even this absolute abyss is thought and therefore the text-Other is thought together as vision-in-One and therefore there is: One or Real. For Derrida this One or Real was haunted by the trace of the Other, whilst for Laruelle there is no haunting, because haunting itself would be one more decision where Real or One is thought on the condition of différance as a quasi-transcendental function effectuating the One or Real as haunted. Thus Laruelle would not argue that the One is writing or the Real is language, because the One is not an object or entity 'in itself' opposed to

19.Non-philosophy 'articulates the idealist pretension of philosophy as that which is able to at least co-determine that Real which is most radical. The counterpoise for this pretension, the price of this sufficiency, is the impossibility for philosophy to constitute a rigorous, non-circular thinking of itself, one which would not beg the constitute a rigorous, non-circular thinking of itself, one which would not beg the
question, that is to say, a theory. Philosophy is self-reflection, self-consciousness; question, that is to say, a theory. Philosophy is self-reflection, self-consciousness;
it thinks, or in the best of case, feels that it thinks when it thinks; this is its cogito. it thinks, or in the best of case, feels that it thinks when it thinks; this is its cogito.
Philosophy never goes beyond a widened cogito, an immanence limited to selfreflection or to self-affection. It is a practice of thought, or a feeling and an affect. Philosophy thereby manifests through this nothing more than its own existence and does not demonstrate that it is the Real to which it lays claim, nor that it knows itself as this pretension. Implicit in its existence is a transcendental hallucination of the Real, and in philosophical "self-knowledge", a transcendental illusion' (Laruelle 1999:139).

20.'The Real, on the other hand, gives philosophy's self-givenness according to its own modality of being-given. Yet, inasmuch as the Real brings forth nothing, and particularly not philosophy, but brings its own being-given (without givenness) to the latter, or, better still, since the latter is in any case given according to its own modality, brings forth philosophy according to the modality of this being-given (without-givenness), then the Real immediately fulfils a transcendental function with regard to philosophy as such. The Real is initially in itself a condition sine qua with regard to philosophy as such. The Real is initially in itself a condition sine qua
non, one which is negative and necessary but not sufficient. But when the variable, non, one which is negative and necessary but not sufficient. But when the variable,
as we shall say, "effectuates" the Real or One, then the latter enters, without as we shall say, "effectuates" the Real or One, then the latter enters, without
alienating itself without losing its character as Real, into a transcendental function through which it relates to philosophy, or, more precisely, through which it brings forth philosophy as given-in-One. We will say that it brings it forth or determines it only-in-the-last-instance' (Laruelle 2000:185-186).

21.'The real One thereby fulfils a transcendental function, whilst remaining the inalienable Real which it is, without changing in nature or "becoming" an other "transcendental One" beside the first. This transcendental cloning on the basis of philosophical material is possible without contradicting the Real's radical autonomy: philosophy is already given in-One and consequently the Real does autonomy: philosophy is already given in-One and consequently the Real does
not enter into contradiction with itself by playing a transcendental role vis-à-vis philosophy. Non-philosophy does not proceed from the transcendental to the Real (and from the a priori to the transcendental) in the manner of philosophy, but from the Real to the transcendental (and from the latter to the $a$ priori)' (Laruelle 1999:144-145). 
language 'in itself' which would form again a philosophical or dialectical pairing of opposites (see Laruelle 1999:140). The vision-in-One is rather a matrix of thought - a thinking or speaking or writing according to the One. You cannot separate the two: language and One, into some kind of duel. It is a radicalisation of there being no outside text (no outside thought) as any attempt at getting outside is still thinking, still language, still writing. Thus writing and its Other has to be thought according to the One. This is not some kind of synthesis between language and One (the Real). It is a nonrelation ${ }^{22}$ as there is no relation, because any relation would be thought and thus it is a unilateral duality: language and presupposed Other are given according to the One: thought or language. The One or text or Context and the Other is a non-relation: a unilateral duality as they are identical in-thelast-instance: things are as they are given to thought.

Thus, to come back to the German Pointer - for Derrida there remained a difference between the name, 'German Pointer', and the Ding-an-sich: the dog out there. Derrida's philosophy is about that difference and the non-relationship between writing and its Other. For Laruelle all there is, is the One or the Real that is the German Pointer as the name and the presupposed Other (referent) are equally given in the immanence of thought as an Advent of thought. For Derrida the 'German Pointer' would be only a name (supplement) that refers via an infinite chain of signifiers never reaching the dog-in-itself. For Laruelle the German pointer together with differrance are thought as One, not as a synthesis or identity, but thought as a unilateral duality as both are thought together as a mixture: world-thought. This means that the name, différance and the impossible Ding-an-sich are all an empirical occasion for thought that is always already thought. The relationship between the three is not an event of thought, but it is the Advent of thought, it is the force (of) thought. It is a vision-in-One as matrix of thought, as a speaking or thinking - according to - the One. Laruelle explains this with his concept of the radical-hyle ${ }^{23}$ as a non-conceptual symbol. A radicalhyle as a non-conceptual symbol (Brassier 2001a:267f.) is not like Derrida's supplement or sign that is conceptually related to its other even if that conceptual relation is a nonrelation. It does not conceptualise the relationship, but posits what is presupposed, the existence of matter, as the first name of matter, as given without givenness. The radical-hyle 'enacts matter's transcendental foreclosure to thought within thought' (Brassier 2001a:10). Therefore, instead of deciding that matter-it-self (Ding-an-sich) is unconceptualisable, unthinkable this unthinkable (unconceptualisable) is already

22 .'The vision-in-One as matrix of thought is a speaking/thinking - according to - the One. Nor is it a relation of synthesis between the One (the Real) and language. It is a non-relation, a "unilateral duality"'(Laruelle 1999:140)

23.'Thus, the radical hyle can be understood neither as a nomination of "matter" qua transcendental signified, which is to say, transcendent metaphysical reality; nor as a conceptual materialisation, in the manner for instance in which the Deleuzoguattarian Concept counter-effectuated an intensively defined materiality. It is neither an empirical conceptualisation of matter nor a transcendental materialisation of the concept. It is a non-conceptual symbol for "matter itself" in its Identity as already-manifested without-manifestation and foreclosed a prior to the materios already-manifested without-manifestation and foreclosed a prior to the materiological differance that tries to substitute an undecidable mixture of already -uttered or uttered-without-statement' (Brassier 2001a:273). within thought. The absolute Other of sign or writing is already within thought. Thus thought and the Other of sign or writing (the Other that is every other) are co-constitutive, given in-One, and thus one clones the radical hyle as the first name of matter itself, but now considered as already given, already manifest and foreclosed to the distinction between conceptualisable and unconceptualisable (see Brassier 2001a:267f.), foreclosed to the distinction between différance and the Other.

In Laruelle's thinking there is no duel between One or Real and decision but they need to be seen in-One and thus as a unilateral duality. The idea of unilaterality is not a stranger to philosophy. Consider specifically Derrida's argument concerning différance (writing), where writing distinguishes itself unilaterally from ' $y$ ' (presence) without ' $y$ ' distinguishing itself from writing ( $\left(x^{\prime}\right)$ in return. Yet at a meta-level - that is, at the level of deconstruction for example as Laruelle argues (2010), or at a level of over-view which is available only to the philosopher - there remains a relation, even if that relation is an absolute non-relation. Thus the unilateral relationship is only on the level of writing and presence, but on the meta-level, Laruelle argues, they are in a duel with each other. What is unique about Laruelle's understanding of the One is that it never is a duel, but a unilateral duality. In other words, the One or Real is seen together with the decision that effectuates the One or Real as its transcendental condition. They are seen together as world-thought and cannot be separated from each other, as any form of separation is still a thought, and therefore Derrida's différance, trace and absolute Other are still thought and thus do not escape thinking or how things appear to thought, which is why for Žižek things do not merely appear; they appear to appear, thereby 'concealing the fact that they are what they appear' (Žižek 2006:235-236). World-thought is thus a mixture of thought and its objects as opposed to various philosophical decisions where there is a combination or synthesis or identity of some form or kind (Alkon \& Gunjevic 2011:219).

For Laruelle thought and its objects are mixed and are seen separate but at the same time identical in immanence (Alkon \& Gunjevic 2011:219). Being and beings are separate, but they are together (identical) in immanence as they are both thoughts. Différance and Other are separate and yet identical in immanence as they are both thoughts. Laruelle takes the entire philosophical apparatus, for example différance and the wholly Other, as given without givenness and as relatively autonomous with respect to the real from which it is foreclosed, but with which it is ultimately or in-the-lastinstance identical as there is no Other beyond thought, and things are as they appear.

The world is no longer presupposed by philosophy as a set of objects knowable as conditioned, but it is seen as a worldthought mixture - a radical-hyle, non-conceptual symbol, as the first name of matter (see Brassier 2001a:267f.). 
This world-thought (radical-hyle) is cloned as a duality that is ultimately identical (in-last-instance-identical) as an identity without synthesis: things are as they appear:

The Real is nothing ontic, ontological, or even heterological - it is an instance of manifestation of the World of philosophy - but a 'last instance', or a power of manifestation - in-the-last-instance. (Laruelle 2000:183)

Derrida says that every other is wholly Other (Derrida 1995:76). This means that the wholly Other is every other and thus, what Chesterton and Žižek say about God as wholly Other is true for every other. God is the unknowable Ding-an-sich, but that is not only true for God, but for all reality. In this way Žižek interprets Christ as the incarnation of the Wholly Other, or said differently the Wholly Other as Ding-an-sich becoming knowable for-us in Christ (see Žižek 2009:55). The Christian narrative of the incarnation can help in understanding Laruelle's non-philosophy. The transcendent Other (tout autre as every other) becomes knowable for-us in the radical-hyle (see Brassier 2001a:267f.), in other words the unknowable material reality (Ding-an-sich) becomes for-us in what Laruelle calls the radical-hyle, the first name of matter. The unknowable Ding-an-sich (reality) becomes for-us in the word made flesh (incarnation), or said differently a 'shift from Decisional idealisation of matter, to the non-Decisional materialisation of Decision' (Brassier 2001a:218). Žižek (2012) argues that Christ is not a symbol or a sign:

Christ does not represent this substantial content, God, he directly is God, which is why he no longer has to resemble God, to strive to be perfect and 'like God'. (p. 164)

One could say that he is axiomatically posited as being God.

The absolutely transcendental reality (Ding-an-sich) not becoming flesh, but word or writing or text or thought is posited as materialisation of Decision for-us. It is the first name of matter, it is writing and a radicalisation that all there is, is writing: 'positing the non-thetic root of decision axiomatically, without presupposing it via decision' (Brassier 2003a:28). Or as Žižek argues that things are as they appear (Žižek 2006:236).

Thus the relation-non-relation to the Other disappears as it is thought in-One. Then the entire World-thought is not in non-relation relation to an unknown Other, but it has been brought into the unknown reality of the future (Alkon \& Gunjevic 2011:219).

The One seen as a vision-in-One is unifacially ${ }^{24}$ turned, not towards the Other because the Other is already included in the vision-in-One in the unilateral-duality, but unifacially turned towards the unknown future..$^{25}$ The unknown future,

24. Non-philosophy is no longer a bifacial or bilateral apparatus like the philosophical one, but one that is unifacial or unilateral. A duality which is an identity but an one, but one that is unifacial or unilateral. A duality which is an identity but an last-instance. Non-philosophy thinks without constituting a system without being unitary' (Laruelle 1999:143).

25. .... weak forcing, the minimal torsion exacted upon philosophy that is ultimately no longer reversible but uni-directional, consequently a future' (Laruelle 2011:254). not in Derrida's sense of the Messianic without Messiah, but rather unifacing an unknown future more in Karl Barth's sense $^{26}$ of the second coming. A future that is made possible because the Advent has happened, Christ has come, and according to Barth that is the only certainty (Word made flesh) and it is not a certainty in the form of knowledge, but a certainty of faith and grace alone (given without givenness). The revelation, as an axiomatic statement, as a given without givenness, is the only uncertain certainty received as a gift of grace and faith. This given without givenness is turned (unifacing) towards the unknown future, and not a messianic future of democracy and justice still to come where there are traces of identity between the past never present and a future always still to come (see Derrida 1982:12, 21), but rather the radically unknown future of Christ's second coming (Barth 2003:45-46) which will reveal all knowledge, philosophy, reasoning as blindness.

\section{Conclusion}

The plurality of the South African context that challenges one's daily existence gives to thinking some interesting material that can be transformed into an event of thought and with sufficient reason (philosophy) developed into a universal (global) ideology of tolerance and interdisciplinarity via the decision of transversal reasoning, or it can be received as an Advent of thought unifacially turned towards an unknown future.

As an Advent of thought it is an alternative space of vulnerability, woundedness and thus utter dependence on grace and faith. The church ${ }^{27}$, with her exemplary Christ narrative, could play a vitally important role in wandering in and wondering at this space: a space of being a stranger in the World. ${ }^{28}$ This is South Africa's hidden potential - nothing essential to South Africa, but the hidden potential of grace and faith beyond certainties in the Advents of the Rainbow Nation.

This opens a different space for non-philosophy, namely the space for faith, the non-philosophical space par excellence: a

26.'God is not hidden to us; He is revealed. But what and how we shall be in Christ, and what and how the World will be in Christ at the end of God's road, at the breaking in of redemption and completion, that is not revealed to us; that is hidden. Let us be honest: we do not know what we are saying when we speak of Jesus Christ's coming again in judgement, and of the resurrection of the dead, of esus Christ's coming again in judgement, and of the resurrection of the dead, of eternal life and eternal death. That with all these there will be bound up a piercing revelation a seeing, compared to which all our present vision will have been blindness - is too often testified in Scripture for us to feel we ought to prepare ourselves fo . For we do not know what will be revealed when the last covering is remove rom our eyes, form all eyes: how we shall behold one another and what we shall be to one another - men of today and men of the past centuries and millennia, ancestors and descendants, husbands and wives, wise and foolish, oppressors and oppressed, traitors and betrayed, murderers and murdered, West and East, Germans and others, Christians, Jews, and heathen, orthodox and heretics, Catholics and Protestants, Lutherans and Reformed; upon what divisions and unions, what confrontations and cross-connections the seals of all books will be opened; how much will only then appear great and important; for what surprises of all kinds we must prepare ourselves. We also do not know what nature, as the cosmos in which we have lived and still live here and now, will be for us then; what the constellations, the sea, the broad valleys and heights, which we see and know now, will say and mean then' (Barth 2003:45-46).

27.When I refer to the 'church' I am specifically referring to the local congregation.

$28 . .$. the subject in accordance with which it is produced ("the Stranger") is not something facing $m e$, it is as a uniface and is for this reason a stranger to the World, a stranger to the law of bilaterality which is proper to philosophy and to the World, but not a stranger to the Real' (Laruelle 1999:143). 
space without reason or decision, a space of pure faith and grace. A space where one is fully aware of the fact that we are parasites who receive, without the ability to return, from the One the unilateral gift as a duality: One and occasional decision, without this One and occasional decision entering into a duel.

This whole discussion has been littered with theological terms and themes and thus the Christ narrative and Christian theology becomes exemplary with regard to this parasitic life of vulnerability where we are completely dependent on the host, the One or Real. Thus the church as the embodiment of these ideas could play an important role in continuously rediscovering our dependence on faith and grace, creating a noological space or a space for multiple connective intellection or non-philosophy; a space filled with awe and wonderment at what is given (this wonderment non-philosophy shares with science in receiving what is given without the question why), but turning both science and the philosophy-World not towards the unknown Other, but towards the future. Not the future of some expected outcome, some utopia of justice or democracy still to come, but the future that is already immanent in the Christ-Advent that will reveal all our thinking as blindness.

The Advent of receiving forgiveness for the unforgivable, the Advent of reconciling the irreconcilable without a code forcing the reconciliation, or a code forcing forgiveness, but receiving the gift of the Advent of the Rainbow Nation - a kingdom where the lion (wolf) and the lamb lie side by side and where the wolf (lion) does not always drink upstream. These Advents cannot be 'used' as building blocks for a nation, these Advents cannot be forced, they are received sacramentally received just as the gifts of Christ's body and blood at the communion table (the Word made flesh: Dingan-sich made for-us). Thus this brings one into the role of the church with regards to noise and différance (the madness of faith and grace), the madness of the impossible possibility of the letter's arrival at its destination, the madness of God the desertification of language (of codes), the desertification of decisions, (impossible decisions) or in Serres's (1982:125f.) thoughts the deafening noise deconstructing the codes and being unifacially turned as stranger-subject to the future. The church can play a role with her Christ narrative, not with dogmas and creeds, but with humble faith: where one is never sure, but all that one has are four soli: Christ, faith, grace and text alone. So the Advents of everyday experiences in South Africa are liberated from the pressure of unity in diversity, the pressure of totality, the pressure of various politically correct discourses, but offered as gifts of a Rainbow Nation. Then this Advent of the Rainbow Nation becomes the gift or the body (text or radical-hyle or non-conceptual symbol) that we share at the table as we break this body (cut and break it with all the scientific, philosophical and political decisions) and then share it unifacially turned to the future as Strangersubjects, aliens and not citizens of this world, and drink the blood from the wounds that knowledge inflicts thereby binding those around the table into a community of love by grace and faith alone facing an unknown future.

\section{Acknowledgements Competing interests}

The author declares that he has no financial or personal relationship(s) which may have inappropriately influenced him in writing this article.

\section{References}

Alkon, G. \& Gunjevic, B., 2011, 'According to the identity of the real: The nonphilosophical thought of immanence', Synthesis philosophica 51(1), 209-227.

Barth, K., 2003, God Here and now, Routledge, New York.

Brassier, R., 2001a, 'Alien Theory: The decline of materialism in the name of matter', PhD thesis, Department of Philosophy, University of Warwick.

Brassier, R., 2001b, 'Behold the non-rabbit: Kant, Quine, Laruelle', Pli: The Warwick Journal of Philosophy 12, 50-82.

Brassier, R., 2003a, 'Axiomatic heresy: The non-philosophy of François Laruelle', Radical Philosophy 121, 24-35

Brassier, R., 2003b, 'Introduction, to what can non-philosophy do?', Angelaki: Journal of the Theoretical Humanities 8(2), 169-172. http://dx.doi. org/10.1080/0969725032000162648

Brown, S.D., 2002, 'Michel Serres: Science, translation and the logic of the parasite', Theory Culture Society 19(1), 1-27. http://dx.doi. org/10.1177/0263276402019003001

Derrida, J., 1975, 'The purveyor of truth', transl. W. Domingo, J. Hulbert \& M. Ron, M-A. Logan (ed.), Yale French Studies: Graphesis: Perspectives in Literature and Philosophy 52, 31-113.

Derrida, J., 1978, 'Violence and metaphysics: An essay on the thought of Emmanuel Levinas', in Writing and difference, transl. A. Bass, pp. 79-153, University of Chicago, Chicago. PMid:25160

Derrida, J., 1981, Dissemination, transl. B. Johnson, Continuum, New York. PMid:6910236

Derrida, J., 1982, Margins of philosophy, transl. A. Bass, Harvester, Brighton.

Derrida, J., 1995, 'Sauf le nom', in J. Derrida \& T. Du Toit (eds.), On the name, transl. D. Wood, J.J. Leavey \& I. McLeod, pp. 35-88, Stanford University Press, Stanford.

Derrida, J., 1997, Of grammatology, transl. G.C. Spivak, John Hopkins Press, Baltimore.

De Saussure, F., 1959, Course in general linguistics, The Philosophical Library, New York.

Kearney, R., 1984, 'Dialogue with Jacques Derrida', in Dialogue with contemporary continental thinkers, pp. 105-126, Manchester University Press, Manchester.

Lacan, J., 1972, 'Seminar on “The Purloined Letter"', transl. J. Mehlman, Yale French Studies: French Freud: Structural Studies in Psychoanalysis 48, 39-72.

Lacan, J., 1991, 'The other side of psychoanalysis', The seminar of Jacques Lacan, Book XVII 1969-1970, transl. R. Grigg, unpublished manuscript.

Laruelle, F., 1999, 'A summary of non-philosophy', Pli: The Warwick Journal of Philosophy 8, 138-148.

Laruelle, F., 2000, 'Identity and event', Pli: The Warwick Journal of Philosophy, Parallel Processes 9, 174-189.

Laruelle, F., 2003, 'What can non-philosophy do?', transl. R Brassier, Angelaki: Journal of the Theoretical Humanities 8(2), 169-189. http://dx.doi. org/10.1080/0969725032000162648

Laruelle, F., 2010, Philosophies of difference: A critical introduction to non-philosophy, transl. R. Gangle, (Kindle edition), Continuum, New York.

Laruelle, F., 2011, 'The generic as predicate and constant: non-philosophy and materialism', in L. Bryant, N. Srnicek \& G. Harman (ed.), The Speculative Turn: Continental Materialism and Realism, pp. 237-260, Re-press, Melbourne.

Levinas, E., 1998, Of God who comes to mind, transl. B. Bergo, Stanford University Press, Stanford.

Meylahn, J.A., 2010, 'Holistic redemptive pastoral ministry in the fragmented transit hall of existence', HTS Teologiese Studies/Theological Studies 66(1), Art. \#426, 9 pages. http://dx.doi.org/10.4102/hts.v66i1.426

Nietzsche, F., 1964, Human, all-too-human: A book for free spirits, part 1, transl. H. Zimmern, Russell \& Russell Inc, New York.

Schrag, C.O., 1992, The Resources of rationality: A response to the postmodern challenge, Indiana University Press, Indianapolis.

Serres, M., 1982, Hermes: Literature, science, philosophy, The John Hopkins University Press, Baltimore. 
Serres, M., 2007, The Parasite, transl. L.R. Schehr, University of Minnesota Press, Minneapolis.

Sharpe, M., 2005, s.v. 'Slavoj Zizek (1949-)', in Internet Encyclopaedia of Philosophy, viewed 07 May 2012, from http://www.iep.utm.edu/zizek/

Van Huyssteen, J.W., 1997, Essays in Postfoundationalist Theology, Eerdmans, Grand Rapids.

Verhaeghe, P., 1995, 'From impossibility to inability: Lacan's theory on the four discourses', The Letter: Lacanian Perspectives on Psychoanalysis 3(Spring), 91-108.

Welsch, W., 2008a, 'Rationality and reason today', from Prof. Dr Wolfgang Welsch Online Texts and Publication Abstracts', in Friedrich-Schiller-Universität Jena, viewed 07 May 2012, from http://www2.uni-jena.de/welsch/
Welsch, W., 2008b, 'Reason and transition; on the concept of transversal reason', from Prof. Dr Wolfgang Welsch Online Texts and Publication Abstracts, viewed 07 May 2012 at, http://www2.uni-jena.de/welsch/

Žižek, S., 2006, 'A plea for a return of différance (with a Minor Pro Domo Sua)', Critical Inquiry 32(Winter), 226-249. http://dx.doi.org/10.1086/500702

Žižek, S., 2009, 'From job to Christ: A Paulinian reading of Chesteron', in J.D. Caputo \& L.M. Alcoff (eds.), St. Paul among the Philosophers, pp. 39-58, Bloomington, Indiana University Press.

Žižek, S., 2012, 'Only a suffering God can save us', in S. Žižek \& B. Gunjevic (eds.), God in pain, pp. 155-192, Seven Stories Press, New York. 